\title{
Studies on Volumetric and Viscometric Properties of L- Glutamic Acid in Aqueous Solution of Glucose over a Range of Temperatures (298K to 323K)
}

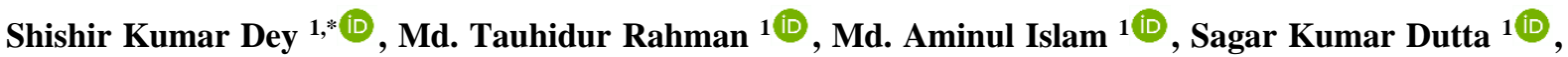 \\ Muhammad Sarwar Hossain 1 (D), Palash Kumar Dhar 1,*(D) \\ 1 Chemistry Discipline, Khulna University, Khulna-9208, Bangladesh; shishir@ku.ac.bd (S.K.D.); tauhid16ku@gmail.com \\ (M.T.R.); 7aminul@gmail.com (M.A.I.); sagar@ku.ac.bd (S.D.); hsarwar86@yahoo.com (M.S.H); palashdhar@ku.ac.bd \\ (P.K.D.); \\ * Correspondence: palashdhar@ku.ac.bd (P.K.D.); shishir@ku.ac.bd (S.K.D.);
}

Scopus Author ID 57190220483

Received: 28.07.2020; Revised: 14.08.2020; Accepted: 15.08.2020; Published: 18.08.2020

\begin{abstract}
In this work, volumetric and viscometric properties of L-glutamic acid in water and aqueous glucose solutions $(5 \%, 10 \%, 15 \%$, and $20 \%$ of glucose, $\mathrm{w} / \mathrm{w}$ in water) have been measured as a function of molal concentration $\left(0.02 \mathrm{~mol} . \mathrm{kg}^{-1}\right.$ to $\left.0.16 \mathrm{~mol} . \mathrm{kg}^{-1}\right)$ of L-glutamic acid at different temperatures $\mathrm{T}=$ $(293.15,303.15,308.15,313.15$ and 323.15) K. By using experimental densities $(\rho)$ and viscosities $(\eta)$ data, apparent molar volume $\left(\varphi_{\mathrm{v}}\right)$, experimental slope $\left(S_{\mathrm{v}}\right)$, limiting apparent molar volume $\left(\varphi_{\mathrm{v}}{ }^{0}\right)$, limiting apparent molar volume transfer $\left(\Delta \varphi_{\mathrm{v}}{ }^{0}\right)_{\text {tra }}$, limiting apparent molar expansibilities $\left(\mathrm{E}_{\varphi}{ }^{0}\right)$, Hepler's constant $\left(\delta \mathrm{E}_{\varphi}{ }^{0} / \delta \mathrm{T}\right)_{\mathrm{p}}$, Falkenhagen coefficient A, and Jones-Dole coefficient B have been computed. Gibbs free energies of activation of viscous flow per mole of solvent $\left(\mu_{1}^{0 \#}\right)$ and per mole of solute $\left(\mu_{2}^{0 \#}\right)$, hydration number $\left(\mathrm{H}_{\mathrm{n}}\right)$ is also calculated. The results are discussed based on solute-solute and solutesolvent interactions in these systems. From the results, it is observed that there exists a structure making propensity of L-glutamic acid in water and in the different mass fraction of aqueous glucose solutions, which increases with the increase of glucose concentrations.
\end{abstract}

Keywords: Apparent molar volume; Hepler's constant; Jones-Dole coefficient B; L-glutamic acid; molecular interactions.

(C) 2020 by the authors. This article is an open-access article distributed under the terms and conditions of the Creative Commons Attribution (CC BY) license (https://creativecommons.org/licenses/by/4.0/).

\section{Introduction}

Macromolecules especially, carbohydrates, lipids, proteins, and nucleic acids, are wellknown biological compounds, which trigger several physiological functions in the human body [1]. Among these, proteins molecules are the most important building block of cytoplasm and cell membranes. The properties of a protein can be well understood by studying the acid-base property of amino acids in aqueous solution [2]. Due to the presence of several non-covalent interactions, including hydrogen-bonding, electrostatic attraction, and hydrophobic interaction, the native structure of a globular protein becomes stable. The stability of protein molecules depends on these non-covalent interactions, which could be affected by the surrounding solute and solvent molecules [3-5]. In addition, direct solute-solvent interaction and/or alteration of water molecules may affect the physicochemical properties of proteins [6-7].

Carbohydrates also act as a stabilizing agent for the native conformation of globular proteins and enzymes [8-9]. Among the different types of carbohydrates, glucose is the most 
abundant monosaccharide that contains both the hydroxyl group $(-\mathrm{OH})$ and the aldehyde group (-CHO). However, glucose plays a pivotal role as an energy source, metabolic intermediary, and important step in cellular respiration [10-13]. Moreover, glucose acts as receptors for the bioactive structures of enzymes, antibodies, hormones, viruses, etc. [14-15].

The protein-carbohydrates interactions are very important in immunology, biosynthesis, pharmacology, medicine, and the cosmetic industry [16-17]. Therefore, extensive studies of amino acids in aqueous carbohydrate solutions are required for a better understanding of solute-solvent interactions [18-19]. Due to the large size of protein macromolecules, the direct study of the physicochemical properties of proteins is difficult. To overcome this problem, the repeating unit of protein molecules such as amino acids, peptides are considered as a model compound for physicochemical studies [20-21]. Based on the nature of the solutesolute and solute-solvent interaction of amino acid in aqueous solutions, the characteristics of a large size protein molecule are easily understood [22-24].

During several decades, researchers are trying to explore new concepts regarding carbohydrate-protein interaction between different solutes and solvents. In a study, Riyazuddeen et al. [25-26] have studied "the interactions in (aqueous sucrose/ aqueous glucose + L-threonine/ L-alanine/) systems at (298.15-323.15) K" and "the densities, viscosities, and speed of sound of L-Proline in aqueous sucrose and glucose solutions". In a similar study, Nain et al. [27-31] have investigated the "solute-solvent and solute-solute interactions of Lserine, L-phenylalanine, L-arginine, L-histidine, and L- threonine in aqueous sucrose, arabinose, and glucose solutions using viscometric and volumetric measurements". Other groups of researchers, Ali et al. [32], have examined "the viscosity, density and refractive index of DL-alanine, glycine, DL-valine, and L-serine in aqueous glucose solution”. Being inspired by this research works, Palani and Geetha [33] have determined "the ultrasonic velocity, density, and viscosity of L-asparagine, L-glutamine and L-serine in aqueous glucose solutions".

To date, there is no volumetric and viscometric data available regarding L-glutamic acid in aqueous carbohydrates solution of different mass fractions at different temperatures. This consideration leads us to undertake this study of L-glutamic acid in aqueous glucose solutions. L-Glutamic acid is an important dicarboxylic amino acid that acts as a neurotransmitter [34]. This paper aims to examine the densities $(\rho)$ and viscosities $(\eta)$ of Lglutamic acid in water and aqueous glucose $(5 \%, 10 \%, 15 \%$, and $20 \%$ of glucose, w/w in water) at $\mathrm{T}=(298.15,303.15,308.15,313.15,318.15$ and 323.15$) \mathrm{K}$. Using the experimental data of $(\rho)$ and $(\eta)$ data, the volumetric properties such as apparent molar volume $\left(\varphi_{v}\right)$, limiting apparent molar volume $\left(\varphi_{\mathrm{v}}{ }^{0}\right)$, limiting apparent molar volume transfer $\left(\Delta \varphi_{\mathrm{v}}{ }^{0}\right)$ tra, limiting apparent molar expansibilities $\left(\mathrm{E}_{\varphi}{ }^{0}\right)$ and Hepler's constant $\left(\delta \mathrm{E}_{\varphi}{ }^{0} / \delta \mathrm{T}\right)_{\mathrm{p}}$ have been determined and viscometric properties like Falkenhagen coefficient of A and Jones-Dole coefficient B, Gibbs free energies of activation of viscous flow per mole of solvent $\left(\mu_{1}^{0 \#}\right)$ and per mole of solute $\left(\mu_{2}^{0 \#}\right)$, hydration number $\left(\mathrm{H}_{\mathrm{n}}\right)$ is also determined. These parameters have been recognized as being sensitive to structural change due to the use to discuss the solute-solute and solute-solvent interactions in these systems.

\section{Materials and Methods}

Highly purified (mass fraction $\geq 99 \%$ ) L-glutamic acid and glucose were purchased from E. Merck (India) (table 1). Using ethanol and water mixture, L-glutamic acid was 
recrystallized, and after drying at $383.15 \mathrm{~K}$, it was placed for at least $72 \mathrm{~h}$ in a vacuum desiccator over $\mathrm{P}_{2} \mathrm{O}_{5}$. Solvent, aqueous glucose $(5,10,15$ and $20 \%$ of glucose, w/w in water) solutions were prepared through doubly distilled water (conductivity less than $1 \times 10^{-6} \mathrm{~S} / \mathrm{cm}$ ) and these solvents were used to make different molal concentrations $(0.02 \mathrm{~mol} / \mathrm{kg}$ to $0.16 \mathrm{~mol} / \mathrm{kg})$ of Lglutamic acid solutions [30]. Moreover, all the mass measurements were carried out by electronic balance with uncertainty $\pm 0.0001 \mathrm{~g}$. For density measurement, a double-arm Ostwald-Sprengel type pycnometer of about $25 \mathrm{~cm}^{3}$ capacity was used, which were calibrated with distilled water at different temperatures. After reaching thermal equilibrium (temperatures 298.15 to $323.15 \mathrm{~K}$ ) of the water bath, the densities of the prepared solutions were determined from the mass of the solution in the density bottle.

To measure viscosity, calibrated British standard U-type Ostwald viscometer was used. The test solution containing a viscometer was placed vertically in the water bath. An electronic watch with an accuracy of $\pm 0.1 \mathrm{~s}$ was used to record the efflux times of flow after the stability of the desired temperature of the water bath. The final efflux time was taken from the average of at least three readings reproducible within $\pm 0.1 \mathrm{~s}$, and the viscosity $(\eta)$ was calculated by using the following equation,

$$
\eta=A \rho t
$$

Where $\mathrm{A}=\frac{\pi \mathrm{r}^{4} \mathrm{hg}}{8 \mathrm{lv}}$ is the viscometer, $\rho$ is density, and $t$ is the final efflux time. However, water viscosities were taken from the literature [35] for calibration purposes.

Table 1. Sample description.

\begin{tabular}{l|l|l|l|l} 
Chemical name & Molecular mass & $\begin{array}{l}\text { Purification } \\
\text { method }\end{array}$ & Source & Mass fraction purity \\
\hline Glucose & $147.13 \mathrm{~g} / \mathrm{mol}$ & Used as received & E. Merck (India) & $\geq 98 \%$ \\
\hline L-glutamic acid & $180.16 \mathrm{~g} / \mathrm{mol}$ & Re-crystallization & E. Merck (India) & $\geq 99 \%$
\end{tabular}

\section{Results and Discussion}

\subsection{Volumetric properties.}

The experimentally measured density $(\rho)$, and viscosity $(\eta)$ for a binary and ternary system of L-glutamic acid in water and aqueous-glucose solution as a function of the molal concentration of L-glutamic acid and temperature: $(298.15 \mathrm{~K}, 303.15 \mathrm{~K}, 308.15 \mathrm{~K}, 313.15 \mathrm{~K}$, $318.15 \mathrm{~K}$, and $323.15 \mathrm{~K}$ ) are listed in table 2.

By using experimental densities, the apparent molar volume $\left(\varphi_{\mathrm{v}}\right)$, the apparent molar volumes at infinite dilution $\left(\varphi_{\mathrm{v}}{ }^{0}\right)$, and the limiting apparent molar volume transfer $\left(\Delta \varphi_{\mathrm{v}}{ }^{0}\right)_{\text {tra }}$ of L-glutamic acid were calculated in solutions with different percentage of aqueous glucose.

Table 2. Densities $(\rho)$, and viscosities $(\eta)$ of solutions of L-glutamic acid in water and (glucose + water) $(5 \%$, $10 \%, 15 \%$ and $20 \%$ glucose, w/w) solutions as functions of molality, m of L-glutamic acid and temperatures

(298.15-323.15) K.

\begin{tabular}{l|l|l|l|l|l|l}
\multirow{2}{*}{$\mathbf{m} /\left(\mathbf{m o l}_{\mathbf{l}} \mathbf{g}^{-1}\right)$} & $\mathbf{3 0 8 . 1 5}$ & $\mathbf{3 0 8 . 1 5}$ & $\mathbf{3 1 3 . 1 5}$ & $\mathbf{3 1 8 . 1 5}$ & $\mathbf{3 2 3 . 1 5}$ \\
\cline { 2 - 7 } & $\mathbf{2 9 8 . 1 5}$ & $\mathbf{3 0 3 . 1 5}$ L-glutamic acid in Water \\
\hline$\rho /\left(\mathrm{kg} . \mathrm{m}^{-3}\right)$ & 1004.00 & 1002.80 & 1001.20 & 999.60 & 997.60 & 995.20 \\
\hline 0.0000 & 1004.82 & 1003.53 & 1001.87 & 1000.23 & 998.18 & 995.71 \\
\hline 0.0191 & 1005.67 & 1004.27 & 1002.55 & 1000.86 & 998.76 & 996.23 \\
\hline 0.0403 & 1006.45 & 1004.94 & 1003.15 & 1001.43 & 999.29 & 996.68 \\
\hline 0.0610 & 1007.05 & 1005.48 & 1003.63 & 1001.87 & 999.68 & 997.06 \\
\hline 0.0786 & 1007.73 & 1006.08 & 1004.20 & 1002.38 & 1000.13 & 997.47 \\
\hline 0.1005 & 1008.24 & 1006.52 & 1004.62 & 1002.78 & 1000.52 & 997.81
\end{tabular}


$\mathbf{m} /\left(\mathbf{m o l . k g} \mathbf{~}^{-1}\right)$

T/K

\begin{tabular}{|c|c|c|c|c|c|c|}
\hline & 298.15 & 303.15 & \begin{tabular}{|l|l|}
308.15 \\
\end{tabular} & 313.15 & 318.15 & 323.15 \\
\hline 0.1398 & 1008.74 & 1007.02 & 1005.02 & 1003.14 & 1000.84 & 998.13 \\
\hline 0.1601 & 1009.26 & 1007.43 & 1005.42 & 1003.42 & 1001.15 & 998.36 \\
\hline \multicolumn{7}{|c|}{$\eta /(m P a . s)$} \\
\hline 0.0000 & 0.8702 & 0.7828 & 0.7134 & 0.6510 & 0.5792 & 0.5143 \\
\hline 0.0191 & 0.8869 & 0.7996 & 0.7276 & 0.6583 & 0.5930 & 0.5248 \\
\hline 0.0403 & 0.9015 & 0.8159 & 0.7392 & 0.6683 & 0.6028 & 0.5401 \\
\hline 0.0610 & 0.9216 & 0.8328 & 0.7579 & 0.6856 & 0.6150 & 0.5541 \\
\hline 0.0786 & 0.9342 & 0.8470 & 0.7682 & 0.6972 & 0.6261 & 0.5643 \\
\hline 0.1005 & 0.9511 & 0.8637 & 0.7830 & 0.7146 & 0.6436 & 0.5745 \\
\hline 0.1190 & 0.9662 & 0.8821 & 0.8037 & 0.7287 & 0.6555 & 0.5880 \\
\hline 0.1398 & 0.9837 & 0.8980 & 0.8232 & 0.7361 & 0.6723 & 0.6073 \\
\hline 0.1601 & 1.0102 & 0.9166 & 0.8347 & 0.7538 & 0.6828 & 0.6281 \\
\hline
\end{tabular}

\begin{tabular}{|c|c|c|c|c|c|c|}
\hline \multicolumn{7}{|c|}{$\rho /\left(\mathrm{kg} \cdot \mathrm{m}^{-3}\right)$} \\
\hline 0.0000 & 1017.61 & 1016.02 & 1014.82 & 1013.27 & 1011.23 & 1009.34 \\
\hline 0.0199 & 1018.56 & 1016.91 & 1015.66 & 1014.07 & 1011.99 & 1010.05 \\
\hline 0.0392 & 1019.42 & 1017.71 & 1016.41 & 1014.78 & 1012.65 & 1010.65 \\
\hline 0.0609 & 1020.32 & 1018.52 & 1017.16 & 1015.49 & 1013.33 & 1011.26 \\
\hline 0.0800 & 1021.04 & 1019.17 & 1017.78 & 1016.04 & 1013.83 & 1011.72 \\
\hline 0.1002 & 1021.76 & 1019.83 & 1018.34 & 1016.58 & 1014.31 & 1012.16 \\
\hline 0.1194 & 1022.43 & 1020.37 & 1018.87 & 1017.01 & 1014.73 & 1012.56 \\
\hline 0.1393 & 1023.04 & 1020.94 & 1019.35 & 1017.43 & 1015.13 & 1012.91 \\
\hline 0.1594 & 1023.62 & 1021.46 & 1019.84 & 1017.84 & 1015.43 & 1013.23 \\
\hline \multicolumn{7}{|c|}{$\eta /(m P a . s)$} \\
\hline 0.0000 & 0.9454 & 0.8578 & 0.7793 & 0.7100 & 0.6394 & 0.5810 \\
\hline 0.0199 & 0.9613 & 0.8755 & 0.8007 & 0.7234 & 0.6553 & 0.5973 \\
\hline 0.0392 & 0.9770 & 0.8937 & 0.8172 & 0.7419 & 0.6703 & 0.6152 \\
\hline 0.0609 & 1.0040 & 0.9226 & 0.8433 & 0.7604 & 0.6883 & 0.6268 \\
\hline 0.0800 & 1.0181 & 0.9350 & 0.8575 & 0.7798 & 0.7051 & 0.6452 \\
\hline 0.1002 & 1.0418 & 0.9530 & 0.8731 & 0.7966 & 0.7216 & 0.6586 \\
\hline 0.1194 & 1.0619 & 0.9713 & 0.8949 & 0.8097 & 0.7350 & 0.6689 \\
\hline 0.1393 & 1.0876 & 1.0015 & 0.9029 & 0.8275 & 0.7588 & 0.6828 \\
\hline 0.1594 & 1.1058 & 1.0241 & 0.9284 & 0.8509 & 0.7696 & 0.7045 \\
\hline \multicolumn{7}{|c|}{ L-glutamic acid in $10 \%$ aq. glucose } \\
\hline \multicolumn{7}{|c|}{$\rho /\left(\right.$ kg. $\left.\mathrm{m}^{-3}\right)$} \\
\hline 0.0000 & 1040.23 & 1038.54 & 1037.02 & 1035.40 & 1033.02 & 1031.20 \\
\hline 0.0201 & 1041.31 & 1039.51 & 1037.88 & 1036.18 & 1033.72 & 1031.83 \\
\hline 0.0407 & 1042.33 & 1040.42 & 1038.67 & 1036.89 & 1034.36 & 1032.41 \\
\hline 0.0599 & 1043.22 & 1041.21 & 1039.36 & 1037.51 & 1034.91 & 1032.92 \\
\hline 0.0797 & 1044.08 & 1041.93 & 1040.03 & 1038.12 & 1035.43 & 1033.43 \\
\hline 0.0998 & 1044.86 & 1042.62 & 1040.67 & 1038.65 & 1035.93 & 1033.89 \\
\hline 0.1200 & 1045.54 & 1043.28 & 1041.25 & 1039.18 & 1036.43 & 1034.35 \\
\hline 0.1406 & 1046.25 & 1043.93 & 1041.82 & 1039.74 & 1036.95 & 1034.76 \\
\hline 0.1601 & 1046.91 & 1044.48 & 1042.24 & 1040.16 & 1037.42 & 1035.14 \\
\hline \multicolumn{7}{|c|}{$\eta /(m P a . s)$} \\
\hline 0.0000 & 1.0776 & 0.9964 & 0.9130 & 0.8179 & 0.7347 & 0.6696 \\
\hline 0.0201 & 1.0958 & 1.0094 & 0.9307 & 0.8361 & 0.7514 & 0.6822 \\
\hline 0.0407 & 1.1124 & 1.0236 & 0.9451 & 0.8623 & 0.7758 & 0.6987 \\
\hline 0.0599 & 1.1305 & 1.0385 & 0.9651 & 0.8837 & 0.7977 & 0.7181 \\
\hline 0.0797 & 1.1460 & 1.0532 & 0.9786 & 0.9072 & 0.8157 & 0.7371 \\
\hline 0.0998 & 1.1650 & 1.0684 & 0.9965 & 0.9270 & 0.8420 & 0.7522 \\
\hline 0.1200 & 1.1839 & 1.0855 & 1.0170 & 0.9466 & 0.8651 & 0.7754 \\
\hline 0.1406 & 1.2043 & 1.1018 & 1.0364 & 0.9719 & 0.8905 & 0.7963 \\
\hline 0.1601 & 1.2286 & 1.1176 & 1.0526 & 0.9931 & 0.9154 & 0.8195 \\
\hline \multicolumn{7}{|c|}{ L-glutamic acid in $15 \%$ aq. glucose } \\
\hline \multicolumn{7}{|c|}{$\rho /\left(\mathrm{kg} \cdot \mathrm{m}^{-3}\right)$} \\
\hline 0.0000 & 1055.40 & 1053.27 & 1051.58 & 1049.47 & 1047.20 & 1044.20 \\
\hline 0.0199 & 1056.58 & 1054.37 & 1052.59 & 1050.40 & 1048.05 & 1044.95 \\
\hline 0.0391 & 1057.66 & 1055.35 & 1053.50 & 1051.24 & 1048.81 & 1045.61 \\
\hline 0.0604 & 1058.79 & 1056.38 & 1054.44 & 1052.09 & 1049.57 & 1046.28 \\
\hline 0.0799 & 1059.75 & 1057.23 & 1055.23 & 1052.82 & 1050.21 & 1046.81 \\
\hline 0.0999 & 1060.68 & 1058.07 & 1055.95 & 1053.49 & 1050.83 & 1047.30 \\
\hline 0.1201 & 1061.57 & 1058.82 & 1056.62 & 1054.12 & 1051.38 & 1047.74 \\
\hline 0.1409 & 1062.42 & 1059.53 & 1057.29 & 1054.70 & 1051.87 & 1048.12 \\
\hline 0.1599 & 1063.13 & 1060.12 & 1057.82 & 1055.21 & 1052.25 & 1048.45 \\
\hline
\end{tabular}




\begin{tabular}{|c|c|c|c|c|c|c|}
\hline \multirow{2}{*}{$\mathrm{m} /\left(\mathrm{mol} \cdot \mathrm{kg}^{-1}\right)$} & \multicolumn{6}{|c|}{$\mathbf{T} / \mathbf{K}$} \\
\hline & 298.15 & 303.15 & 308.15 & 313.15 & 318.15 & 323.15 \\
\hline \multicolumn{7}{|c|}{$\eta /(m P a . s)$} \\
\hline 0.0000 & 1.3403 & 1.2120 & 1.0717 & 0.9447 & 0.8451 & 0.7642 \\
\hline 0.0199 & 1.3575 & 1.2290 & 1.0879 & 0.9659 & 0.8623 & 0.7759 \\
\hline 0.0391 & 1.3797 & 1.2457 & 1.1091 & 0.9844 & 0.8794 & 0.7902 \\
\hline 0.0604 & 1.4017 & 1.2581 & 1.1285 & 1.0109 & 0.9013 & 0.8104 \\
\hline 0.0799 & 1.4187 & 1.2880 & 1.1440 & 1.0349 & 0.9178 & 0.8218 \\
\hline 0.0999 & 1.4409 & 1.3053 & 1.1729 & 1.0537 & 0.9361 & 0.8353 \\
\hline 0.1201 & 1.4704 & 1.3294 & 1.1949 & 1.0850 & 0.9548 & 0.8474 \\
\hline 0.1409 & 1.4899 & 1.3570 & 1.2159 & 1.1146 & 0.9724 & 0.8649 \\
\hline 0.1599 & 1.5132 & 1.3825 & 1.2357 & 1.1409 & 0.9934 & 0.8827 \\
\hline \multicolumn{7}{|c|}{ L-glutamic acid in $20 \%$ aq. glucose } \\
\hline \multicolumn{7}{|c|}{$\rho /\left(\mathrm{kg} \cdot \mathrm{m}^{-3}\right)$} \\
\hline 0.0000 & 1077.40 & 1075.30 & 1072.12 & 1069.68 & 1066.80 & 1064.33 \\
\hline 0.0201 & 1078.63 & 1076.47 & 1073.23 & 1070.74 & 1067.80 & 1065.27 \\
\hline 0.0403 & 1079.80 & 1077.58 & 1074.26 & 1071.72 & 1068.73 & 1066.15 \\
\hline 0.0609 & 1080.95 & 1078.61 & 1075.30 & 1072.67 & 1069.58 & 1066.98 \\
\hline 0.0810 & 1081.96 & 1079.59 & 1076.17 & 1073.47 & 1070.36 & 1067.70 \\
\hline 0.1000 & 1083.01 & 1080.46 & 1077.05 & 1074.32 & 1071.12 & 1068.40 \\
\hline 0.1199 & 1083.86 & 1081.37 & 1077.86 & 1075.13 & 1071.83 & 1069.00 \\
\hline 0.1420 & 1084.87 & 1082.3 & 1078.73 & 1075.96 & 1072.47 & 1069.68 \\
\hline 0.1594 & 1085.52 & 1082.86 & 1079.45 & 1076.54 & 1073.04 & 1070.13 \\
\hline \multicolumn{7}{|c|}{$\eta /(m P a . s)$} \\
\hline 0.0000 & 1.6047 & 1.4363 & 1.2617 & 1.0922 & 0.9884 & 0.8733 \\
\hline 0.0201 & 1.6264 & 1.4570 & 1.2751 & 1.1125 & 1.0024 & 0.8924 \\
\hline 0.0403 & 1.6392 & 1.4753 & 1.2968 & 1.1363 & 1.0199 & 0.9142 \\
\hline 0.0609 & 1.6605 & 1.4946 & 1.3253 & 1.1644 & 1.0543 & 0.9444 \\
\hline 0.0810 & 1.6860 & 1.5270 & 1.3406 & 1.1911 & 1.0624 & 0.9486 \\
\hline 0.1000 & 1.7138 & 1.5520 & 1.3834 & 1.2180 & 1.0773 & 0.9613 \\
\hline 0.1199 & 1.7474 & 1.5822 & 1.4078 & 1.2362 & 1.0946 & 0.9875 \\
\hline 0.1420 & 1.7808 & 1.6097 & 1.4480 & 1.2681 & 1.1268 & 1.0146 \\
\hline 0.1594 & 1.8161 & 1.6348 & 1.4707 & 1.2852 & 1.1575 & 1.0510 \\
\hline
\end{tabular}

3.1.1. Apparent molar volume.

The apparent molar volume $\left(\varphi_{\mathrm{v}}\right)$, of L-glutamic acid, was calculated by using the relation,

$$
\varphi_{v}=\frac{\left(\rho_{o}-\rho\right)}{m \rho \rho_{0}}+\frac{M}{\rho}
$$

Where, $\mathrm{m}=$ molality $\left(\mathrm{mol} \cdot \mathrm{kg}^{-1}\right)$ of the solution, $\mathrm{M}=$ molar mass of the solute $\left(\mathrm{kg} \cdot \mathrm{mol}^{-1}\right), \rho_{o}$ and $\rho=$ densities of solvent and solution, respectively. The variations of $\varphi_{\mathrm{v}}$ as a function of $\mathrm{L}$ glutamic acid at various concentrations and temperatures are represented in figure 1.

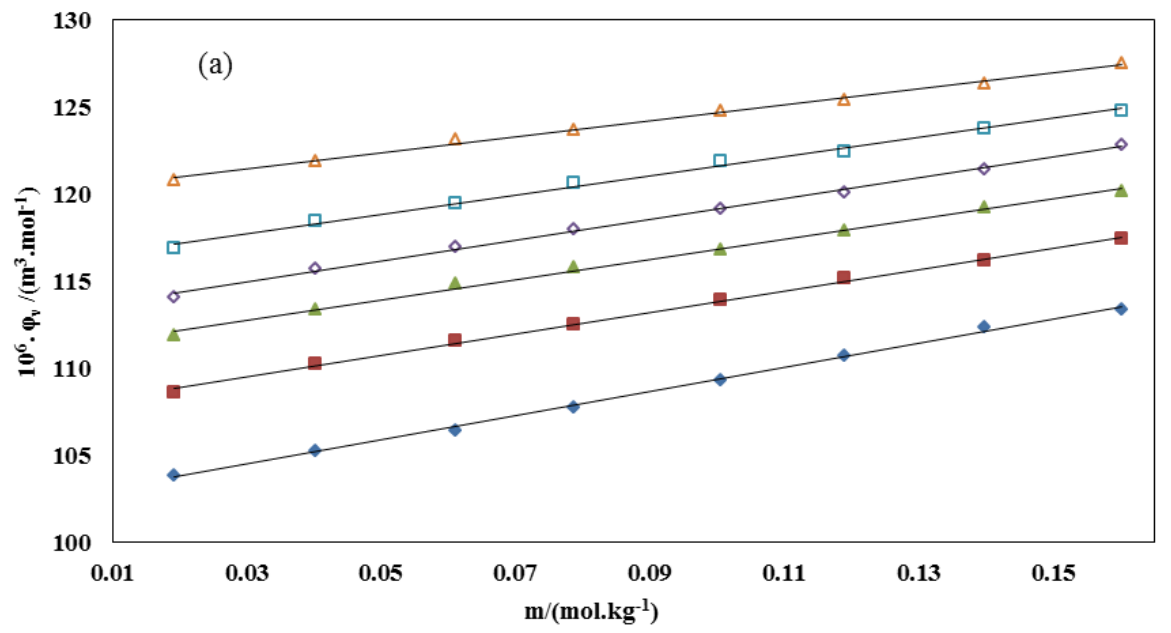



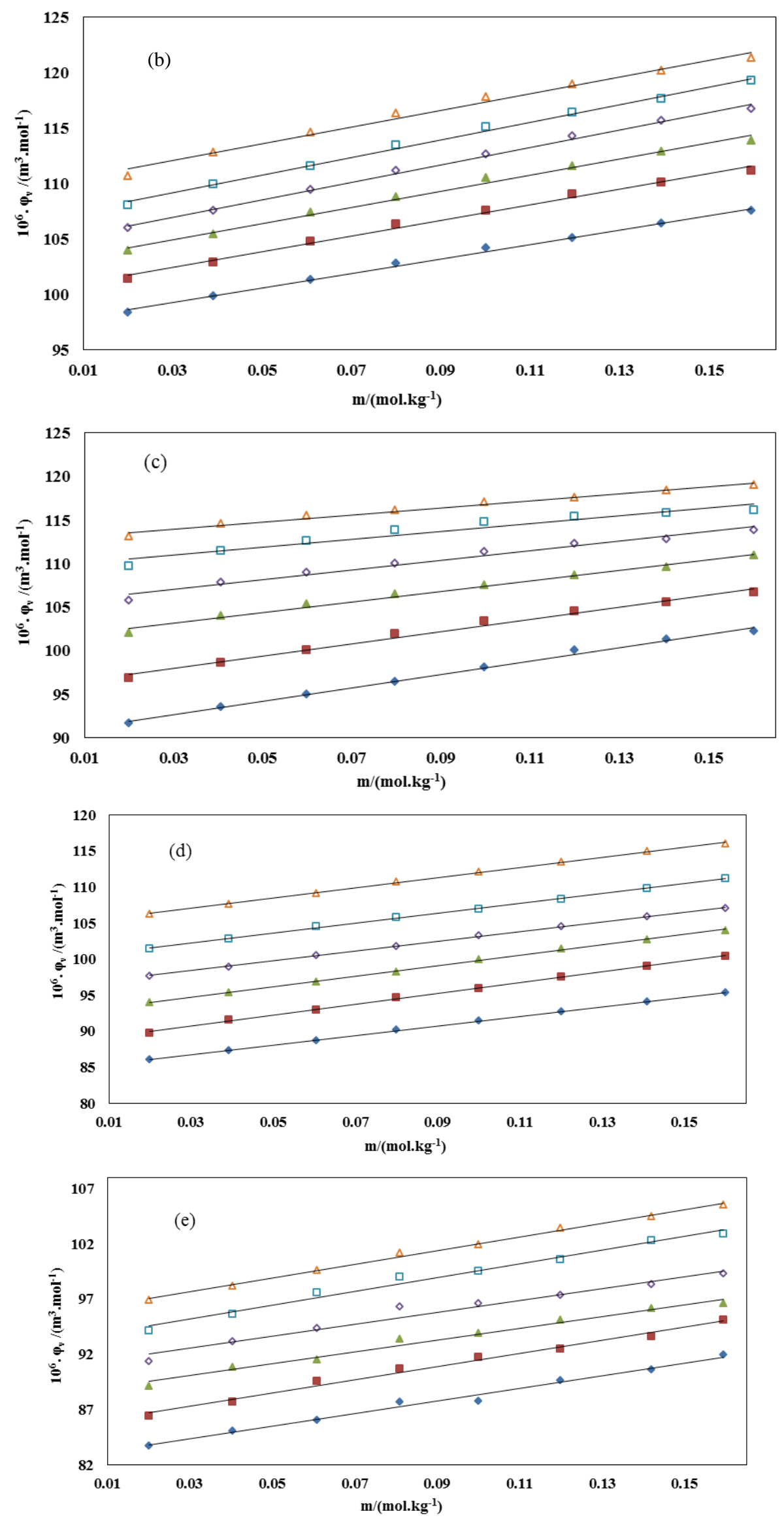

Figure 1. Variations of apparent molar volume, $\varphi_{V}$ vs. molality, $\mathrm{m}$ of 1-glutamic acid in water and in aqueous glucose (w/w) solutions, (a) water (b) 5\% glucose, (c) $10 \%$ glucose, (d) $15 \%$ glucose, (e) $20 \%$ glucose, at temperatures, $\mathrm{T} / \mathrm{K}=293.15, \bullet \mathrm{T} / \mathrm{K}=298.15, \mathbf{m} ; \mathrm{T} / \mathrm{K}=303.15, \mathbf{\Delta} ; \mathrm{T} / \mathrm{K}=308.15, \diamond ; \mathrm{T} / \mathrm{K}=313.15, \square ; \mathrm{T} / \mathrm{K}=$ $318.15, \Delta$. 
From this figure, it is seen that the curves of $\varphi_{v}$ vs. $m$ are linear for L-glutamic acid in water and in all the four aqueous-glucose solvents in the studies concentration range and at each investigated temperature. Moreover, the $\varphi_{v}$ for L-glutamic acid increase with arising the concentration of L-glutamic acid and increasing temperature, but these values are reduced by increasing the percentage of glucose. A similar phenomenon is noticed in the case of L-proline in aqueous metformin hydrochloride solutions [36]. These types of results indicate the presence of strong interaction between L-glutamic acid and glucose molecules.

\subsubsection{Limiting apparent molar volume.}

The limiting apparent molar volumes or apparent molar volumes at infinite dilution $\left(\varphi_{\mathrm{v}}{ }^{0}\right)$ were calculated using the Masson equation [37].

$$
\varphi_{v}=\varphi_{v}^{0}+S_{v} m
$$

Where $S_{\mathrm{v}}=$ the experimental slope or volumetric pairwise interaction coefficient [38], which gives an idea about the solute-solute interaction, the $\varphi_{v}{ }^{0}$ provides information regarding solutesolvent interaction, and $m$ is the molality of L-glutamic acid in aqueous glucose solution. The values of $\varphi_{v}{ }^{0}$ and $S_{v}$ are listed in table 3. According to this table, it can be seen that the values of $\mathrm{S}_{\mathrm{v}}$ for L-glutamic acid in different percentages of glucose from a range of temperatures (298.15 to 323.15) $\mathrm{K}$ are positive, indicating the existence of solute-solute interactions. The values of $\varphi_{v}{ }^{0}$ are positive for all the systems, which is an indication of the presence of solutesolvent interactions. The values of $\varphi_{v}{ }^{0}$ increase with rising temperature due to the reduction of electrostriction of water. The smaller values of $S_{\mathrm{v}}$ as compared to $\varphi_{\mathrm{v}}{ }^{0}$ suggest the dominance of solute-solvent interaction over the solute-solute interaction. The findings of the present study are supported by the researches of other researchers [39-41].

Table 3. Limiting apparent molar volumes at infinite dilution $\left(\varphi_{\mathrm{v}}{ }^{0}\right)$, experimental slope $\left(\mathrm{S}_{\mathrm{v}}\right)$, limiting apparent molar volume transfer $\left(\Delta \varphi_{\mathrm{v}}{ }^{0}\right)_{\text {tra }}$, limiting apparent molar expansibilities $\left(\mathrm{E}_{\varphi}{ }^{0}\right)$, Hepler constant $\left(\delta \mathrm{E}_{\varphi}{ }^{0} / \delta \mathrm{T}\right)_{\mathrm{p}}$ of Lglutamic acid in water and (glucose + water) $(5 \%, 10 \%, 15 \%$ and $20 \%$ glucose, w/w) solutions at temperatures

\begin{tabular}{|c|c|c|c|c|c|}
\hline \multicolumn{6}{|c|}{$(298.15-323.15) \mathrm{K}}$. \\
\hline $\mathbf{T} / \mathbf{K}$ & $\begin{array}{l}10^{6} \cdot \varphi_{\mathrm{v}}{ }^{0} / \\
\left(\mathbf{m}^{3} \cdot \mathrm{mol}^{-1}\right)\end{array}$ & $\begin{array}{l}10^{6} \cdot \mathrm{S}_{\mathrm{v}} / \\
\left(\mathrm{m}^{3} \cdot \mathrm{mol}^{-2} \cdot \mathrm{kg}\right)\end{array}$ & $\begin{array}{l}10^{6} \cdot\left(\Delta \varphi_{\mathrm{v}}{ }^{0}\right) \text { tra } / \\
\left(\mathrm{m}^{3} \cdot \mathrm{mol}^{-1}\right)\end{array}$ & $\begin{array}{l}10^{8} \cdot \mathbf{E}_{\varphi} \% / \\
\left(\mathbf{m}^{3} \cdot \mathbf{m o l}^{-1} \cdot \mathbf{K}^{-1}\right)\end{array}$ & $\begin{array}{l}10^{8} \cdot\left(\delta \mathbf{E}^{0}{ }_{\phi} / \delta \mathbf{T}\right)_{\mathrm{p}} / \\
\left(\mathbf{m}^{3} \cdot \mathbf{m o l}^{-1} \cdot \mathbf{K}^{-2}\right)\end{array}$ \\
\hline \multicolumn{6}{|c|}{ L-glutamic acid in water } \\
\hline 298.15 & $102.41( \pm 0.1466)$ & $69.30( \pm 1.6437)$ & - & 49.55 & \multirow{6}{*}{0.54} \\
\hline 303.15 & $107.69( \pm 0.1324)$ & $61.52( \pm 1.4849)$ & - & 54.95 & \\
\hline 308.15 & $111.05( \pm 0.1633)$ & $57.90( \pm 1.8306)$ & - & 57.65 & \\
\hline 313.15 & $113.20( \pm 0.1496)$ & $59.51( \pm 1.6775)$ & - & 60.35 & \\
\hline 318.15 & $116.11( \pm 0.1707)$ & $54.86( \pm 1.9135)$ & - & 63.05 & \\
\hline 323.15 & $120.10( \pm 0.1453)$ & $45.54( \pm 1.6291)$ & - & 65.75 & \\
\hline \multicolumn{6}{|c|}{ L-glutamic acid in 5\% aq. glucose } \\
\hline 298.15 & $97.32( \pm 0.1652)$ & $65.44( \pm 1.8513)$ & -5.09 & 27.20 & \multirow{6}{*}{0.94} \\
\hline 303.15 & $100.30( \pm 0.2130)$ & $70.74( \pm 2.3869)$ & -7.39 & 36.56 & \\
\hline 308.15 & $102.78( \pm 0.1937)$ & $72.46( \pm 2.1704)$ & -8.27 & 41.24 & \\
\hline 313.15 & $104.59( \pm 0.1243)$ & $78.95( \pm 1.3928)$ & -8.60 & 45.92 & \\
\hline 318.15 & $106.77( \pm 0.2102)$ & $79.65( \pm 2.3559)$ & -9.34 & 50.60 & \\
\hline 323.15 & $109.81( \pm 0.3190)$ & $75.39( \pm 3.5749)$ & -10.29 & 55.28 & \\
\hline \multicolumn{6}{|c|}{ L-glutamic acid in $10 \%$ aq. glucose } \\
\hline 298.15 & $90.38( \pm 0.1394)$ & $76.80( \pm 1.5565)$ & -12.03 & 68.48 & \multirow{6}{*}{0.63} \\
\hline 303.15 & $95.87( \pm 0.2790)$ & $70.37( \pm 3.1152)$ & -11.83 & 74.74 & \\
\hline 308.15 & $101.35( \pm 0.2923)$ & $60.75( \pm 3.2645)$ & -9.71 & 77.87 & \\
\hline 313.15 & $105.41( \pm 0.3662)$ & $55.10( \pm 4.0899)$ & -7.79 & 81.00 & \\
\hline 318.15 & $109.64( \pm 0.4289)$ & $45.37( \pm 4.7892)$ & -6.48 & 84.13 & \\
\hline 323.15 & $112.77( \pm 0.2173)$ & $40.68( \pm 2.4268)$ & -7.33 & 87.26 & \\
\hline \multicolumn{6}{|c|}{ L-glutamic acid in $15 \%$ aq. glucose } \\
\hline 298.15 & $84.79( \pm 0.0609)$ & $66.12( \pm 0.6792)$ & -17.62 & 34.00 & \\
\hline 303.15 & $88.47( \pm 0.1148)$ & $75.15( \pm 1.2815)$ & -19.22 & 56.80 & \\
\hline
\end{tabular}




\begin{tabular}{|c|c|c|c|c|c|}
\hline $\mathbf{T} / \mathbf{K}$ & $\begin{array}{l}10^{6} \cdot \varphi_{\mathrm{v}}{ }^{\%} / \\
\left(\mathbf{m}^{3} \cdot \mathbf{m o l}^{-1}\right)\end{array}$ & $\begin{array}{l}10^{6} . \mathrm{S}_{\mathrm{v}} / \\
\left(\mathrm{m}^{3} . \mathrm{mol}^{-2} . \mathrm{kg}\right)\end{array}$ & $\begin{array}{l}10^{6} \cdot\left(\Delta \varphi_{\mathrm{v}}{ }^{0}\right) \mathrm{tra} / \\
\left(\mathbf{m}^{3} \cdot \mathrm{mol}^{-1}\right)\end{array}$ & $\begin{array}{l}10^{8} \cdot \mathbf{E}_{\varphi}{ }^{0} / \\
\left(\mathbf{m}^{3} \cdot \mathbf{m o l}^{-1} \cdot \mathbf{K}^{-1}\right)\end{array}$ & $\begin{array}{l}\mathbf{1 0}^{8} \cdot\left(\delta \mathbf{E}^{0} / \boldsymbol{\delta} \mathbf{T}\right)_{\mathrm{p}} / \\
\left(\mathbf{m}^{3} \cdot \mathbf{m o l}^{-1} \cdot \mathbf{K}^{-2}\right)\end{array}$ \\
\hline 308.15 & $92.50( \pm 0.1023)$ & $72.89( \pm 1.1411)$ & -18.56 & 68.20 & \multirow[t]{4}{*}{2.28} \\
\hline 313.15 & $96.39( \pm 0.0548)$ & $67.60( \pm 0.6117)$ & -16.81 & 79.60 & \\
\hline 318.15 & $100.20( \pm 0.1057)$ & $68.45( \pm 1.1797)$ & -15.92 & 91.00 & \\
\hline 323.15 & $104.92( \pm 0.0553)$ & $70.79( \pm 0.6165)$ & -15.18 & 102.40 & \\
\hline \multicolumn{6}{|c|}{ L-glutamic acid in $20 \%$ aq. glucose } \\
\hline 298.15 & $82.64( \pm 0.2794)$ & $57.22( \pm 3.1003)$ & -19.77 & 32.43 & \multirow{6}{*}{0.85} \\
\hline 303.15 & $85.50( \pm 0.3093)$ & $59.90( \pm 3.4329)$ & -22.20 & 40.89 & \\
\hline 308.15 & $88.47( \pm 0.2726)$ & $53.56( \pm 3.0256)$ & -22.58 & 45.12 & \\
\hline 313.15 & $90.96( \pm 0.4689)$ & $53.97( \pm 5.2034)$ & -22.24 & 49.34 & \\
\hline 318.15 & $93.32( \pm 0.3345)$ & $62.25( \pm 3.7126)$ & -22.79 & 53.57 & \\
\hline 323.15 & $95.78( \pm 0.1792)$ & $62.03( \pm 1.9883)$ & -24.32 & 57.80 & \\
\hline
\end{tabular}

3.1.3. Limiting apparent molar volume transfer $\left(\Delta \varphi_{v}{ }^{0}\right)_{\text {tra. }}$

The Limiting apparent molar volume transfer $\left(\Delta \varphi_{\mathrm{v}}{ }^{0}\right)$ tra for L-glutamic acid from water to the aqueous glucose mixture can be calculated from the following equation, [42]: $\left(\Delta \varphi_{\mathrm{v}}{ }^{0}\right)_{\text {tra }}=\varphi_{\mathrm{v}}{ }^{0}(\mathrm{~L}-$ glutamic acid in aq. glucose solution $)-\varphi_{\mathrm{v}}{ }^{0}(\mathrm{~L}$-glutamic acid in water $)$

The $\left(\Delta \varphi_{v}{ }^{0}\right)_{\text {tra }}$ is free from solute-solute interactions but only depends on the solute-solvent interactions [43]. In this study, the interaction occurring between L-glutamic acid and aqueous glucose solution could be categorized as follows [30, 44, 45]:

I. -OH groups of glucose interact with zwitterions $\left(\mathrm{NH}_{3}{ }^{+}, \mathrm{COO}^{-}\right)$of amino acids through ionic-hydrophilic interaction.

II. Hydrophilic-hydrophilic interactions present in $\mathrm{OH}$ groups of glucose and side-chain $\mathrm{OH}$ groups of L-glutamic acid through H-bonding.

III. Non-polar groups of glucose (alkyl chain) and zwitterionic groups $\left(\mathrm{NH}_{3}{ }^{+}, \mathrm{COO}^{-}\right)$of $\mathrm{L}-$ glutamic acid interrelate with hydrophobic-ionic interaction.

IV. Hydrophobic-hydrophobic interactions link-up between non-polar $\left(-\mathrm{CH}_{3}\right)$ in the side chain of L-glutamic acid and alkyl chain of glucose.

V. Hydrophobic-hydrophilic interactions linkage between non-polar groups of L-glutamic acid and the $-\mathrm{OH}$ groups of glucose.

Type (I) and (II) interaction are responsible for a positive contribution to the $\left(\Delta \varphi_{\mathrm{v}}{ }^{0}\right)_{\text {tra, }}$ since the overlap of the hydration co-sphere of charged ions $\left(\mathrm{NH}_{3}{ }^{+}, \mathrm{COO}^{-}\right)$, hydrophilic groups $\left(-\mathrm{NH}_{2},-\mathrm{OH}\right)$ and $-\mathrm{OH}$ groups could lead to the reduction of electrostriction of water molecules lying in the proximity of these amino acids and type (III), (IV), and (V) contribute negatively to the $\left(\Delta \varphi_{\mathrm{v}}{ }^{0}\right)$ tra due to disruption of side group hydration by that of the charged end [45].

From table 3, it is observed that all values of the limiting apparent molar volume transfer $\left(\Delta \varphi_{\mathrm{v}}{ }^{0}\right)_{\text {tra }}$ are negative. So it indicates that the interactions of type (3), (4), and (5) are dominated in the studied systems.

3.1.4. Limiting apparent molar volume expansibilities $\mathrm{E}_{\varphi}{ }^{0}$ and Hepler Constant $\left(\delta \mathrm{E}_{\varphi}{ }^{0} / \delta \mathrm{T}\right)_{\mathrm{p}}$,

The variation of $\varphi_{\mathrm{v}}{ }^{0}$ with the temperature at infinite dilution can be represented by the following polynomial equation [46]:

$$
\varphi_{v}^{0}=\mathrm{a}+\mathrm{b}\left(\mathrm{T}-\mathrm{T}_{\mathrm{m}}\right)+\mathrm{c}\left(\mathrm{T}-\mathrm{T}_{\mathrm{m}}\right)^{2}
$$

Where $\mathrm{T}=$ temperature (Kelvin), $\mathrm{T}_{\mathrm{m}}=$ the average temperature (Kelvin), and $\mathrm{a}, \mathrm{b}$, and $\mathrm{c}=$ the empirical constants. The limiting apparent molar expansibilities or first derivatives of the temperature dependence of limiting apparent molar volumes are obtained as follows:

$$
\frac{\delta\left(\varphi_{v}^{0}\right)}{\delta\left(T-T_{m}\right)}=\mathrm{E}_{\varphi}^{0}=\mathrm{b}+2 \mathrm{c}\left(\mathrm{T}-\mathrm{T}_{\mathrm{m}}\right)
$$


The calculated values of $\mathrm{E}_{\varphi}{ }^{0}$ are listed in table 3. The values of $\mathrm{E}_{\varphi}{ }^{0}$ of any solute expose the solute-solvent interaction [47]. From this table, the values of $\mathrm{E}_{\varphi}{ }^{0}$ are positive for L-glutamic acid in water and all four systems of aqueous solutions of glucose, suggesting the presence of solute-solvent interactions in these systems, as already indicated by apparent molar volume data. Yan et al. [48] have found a similar trend of $\mathrm{E}_{\varphi}{ }^{0}$ in some amino acids and a pharmaceutically active ionic liquid domiphen DL-mandelic acid in aqueous medium at temperatures from $293.15 \mathrm{~K}$ to $313.15 \mathrm{~K}$.

Hepler [49] developed the general thermo-dynamic expression to determine the capacity of solute as a structure maker or structure breaker in a mixed solvent system using the general thermodynamic expression:

$$
\frac{\delta^{2}\left(\varphi_{v}^{0}\right)}{\delta^{2}\left(T-T_{m}\right)}=\left(\delta \mathrm{E}_{\varphi}^{0} / \delta \mathrm{T}\right)_{\mathrm{p}}=2 \mathrm{c}
$$

Solute acts as structure-maker when the values of $\left(\delta \mathrm{E}_{\varphi}{ }^{0} / \delta \mathrm{T}\right)_{\mathrm{p}}$ are positive, whereas a solute acts as structure-breaker when the values of $\left(\delta \mathrm{E}_{\varphi}{ }^{0} / \delta \mathrm{T}\right)_{\mathrm{p}}$ are negative [50]. In this work, the values of $\left(\delta \mathrm{E}_{\varphi}{ }^{0} / \delta \mathrm{T}\right)_{\mathrm{p}}$ are positive, which are indexed in table 3 , and that indicates the structure-maker property of L-glutamic acid in water and aqueous glucose solutions.

\subsection{Viscometric properties.}

\subsubsection{Viscosity coefficient- B and A.}

Viscosities of L-glutamic acid in aqueous and in aqueous glucose solutions are measured at 293.15, 298.15, 303.15, 308.15, and $313.15 \mathrm{~K}$ respectively and indexed in table 2 . It is observed that the viscosities increase with increasing the concentration of L-glutamic acid and decrease with increasing the temperature. When a solute is subjected to dissolved in a solvent, some of the solvents molecules interact with the solutes, as the result of solute-solvent interaction that slows down the mobility of the liquid for this the value of viscosities are increased with increasing the concentration of L-glutamic acid [51]. As the temperature increasing, the kinetic energy of the molecule is increased, which increases the mobility of the liquid; therefore, the values of viscosities are decreased with increasing temperature. Increasing the viscosities by adding the solute indicates the structure making ability of the solute [52]. The detailed information about solute-solute and solute-solvent interaction of the system is provided by the resulting Falkenhagen and Jones-Dole viscosity B-coefficients [53-54]. There is a linear relationship between the viscosity and the molality of the L-glutamic acid in aqueous glucose system. So, the coefficient A (Falkenhagen coefficient) and Jones-Dole viscosity Bcoefficient are calculated from the Jones-Dole equation that is given below:

$$
\frac{\eta_{r}-1}{\sqrt{m}}=A+B \sqrt{m}
$$

Where, $\eta_{\mathrm{r}}=$ the relative viscosity of the solution and $\mathrm{m}$ molality of L-glutamic acid, A and B $=$ the Falkenhagen and Jones-Dole coefficients, respectively. From the intercept and slope of the plots of $\left(\eta_{\mathrm{r}}-1\right) / \mathrm{m}^{1 / 2}$ versus $\mathrm{m}^{1 / 2}$, the values of $\mathrm{A}$ and $\mathrm{B}$ coefficient is measured and displayed in table 4. The positive value of B-coefficient is associated with strong solute-solvent interaction and also with structure making ability of solute, while a negative value of Bcoefficient is associated with structure-breaking properties between solute and solvent [55-56]. The coefficient-A represents the solute-solute interaction associated with the size and shape of the solute. The negative values of the A coefficient indicate the presence of very weak solutesolute interactions; the positive values of the A coefficient indicate the presence of significant solute-solute interactions [57]. 
Table 4. The viscosity coefficient values $\mathrm{B}, \mathrm{A}$, and hydration number, $\left(\mathrm{H}_{\mathrm{n}}\right)$ for L-glutamic acid in water and (glucose + water) $(5 \%, 10 \%, 15 \%$, and $20 \%$ glucose, w/w) solutions at temperatures $(298.15-323.15) \mathrm{K}$.

\begin{tabular}{|c|c|c|c|}
\hline $\mathbf{T} / \mathbf{K}$ & B/(kg.mol $\left.{ }^{-1}\right)$ & $\mathrm{A} /\left(\mathrm{kg}^{1 / 2} \cdot \mathrm{mol}^{-1 / 2}\right)$ & $\mathbf{H}_{\mathbf{n}}$ \\
\hline \multicolumn{4}{|c|}{ L-glutamic acid in water } \\
\hline 298.15 & $0.9671( \pm 0.032)$ & $-0.0054( \pm 0.009)$ & 0.94 \\
\hline 303.15 & $1.0415( \pm 0.027)$ & $0.0042( \pm 0.008)$ & 0.97 \\
\hline 308.15 & $1.1391( \pm 0.088)$ & $-0.0326( \pm 0.025)$ & 1.03 \\
\hline 313.15 & $1.2343( \pm 0.074)$ & $-0.0952( \pm 0.021)$ & 1.09 \\
\hline 318.15 & $1.1376( \pm 0.095)$ & $-0.0119( \pm 0.027)$ & 0.98 \\
\hline 323.15 & $1.4169( \pm 0.081)$ & $-0.0479( \pm 0.023)$ & 1.18 \\
\hline \multicolumn{4}{|c|}{ L-glutamic acid in 5\% aq. glucose } \\
\hline 298.15 & $1.2164( \pm 0.053)$ & $-0.0607( \pm 0.015)$ & 1.25 \\
\hline 303.15 & $1.2655( \pm 0.086)$ & $-0.0333( \pm 0.024)$ & 1.26 \\
\hline 308.15 & $1.0717( \pm 0.080)$ & $-0.0464( \pm 0.023)$ & 1.04 \\
\hline 313.15 & $1.3418( \pm 0.054)$ & $-0.0455( \pm 0.015)$ & 1.28 \\
\hline 318.15 & $1.3351( \pm 0.051)$ & $-0.0168( \pm 0.014)$ & 1.25 \\
\hline 323.15 & $1.1899( \pm 0.077)$ & $-0.0407( \pm 0.022)$ & 1.08 \\
\hline \multicolumn{4}{|c|}{ L-glutamic acid in $10 \%$ aq. glucose } \\
\hline 298.15 & $0.8773( \pm 0.023)$ & $-0.0144( \pm 0.007)$ & 0.97 \\
\hline 303.15 & $0.8280( \pm 0.013)$ & $-0.0296( \pm 0.004)$ & 0.86 \\
\hline 308.15 & $0.9800( \pm 0.046)$ & $-0.0129( \pm 0.013)$ & 0.97 \\
\hline 313.15 & $1.4175( \pm 0.062)$ & $-0.0271( \pm 0.017)$ & 1.34 \\
\hline 318.15 & $1.7199( \pm 0.046)$ & $-0.0796( \pm 0.013)$ & 1.57 \\
\hline 323.15 & $1.6353( \pm 0.043)$ & $-0.1079( \pm 0.012)$ & 1.45 \\
\hline \multicolumn{4}{|c|}{ L-glutamic acid in $15 \%$ aq. glucose } \\
\hline 298.15 & $0.8787( \pm 0.036)$ & $-0.0319( \pm 0.010)$ & 1.04 \\
\hline 303.15 & $0.9861( \pm 0.078)$ & $-0.0578( \pm 0.022)$ & 1.11 \\
\hline 308.15 & $1.0658( \pm 0.050)$ & $-0.0434( \pm 0.014)$ & 1.15 \\
\hline 313.15 & $1.4043( \pm 0.065)$ & $-0.0563( \pm 0.018)$ & 1.46 \\
\hline 318.15 & $1.1184( \pm 0.023)$ & $-0.0123( \pm 0.007)$ & 1.12 \\
\hline 323.15 & $1.0217( \pm 0.061)$ & $-0.0268( \pm 0.017)$ & 0.97 \\
\hline \multicolumn{4}{|c|}{ L-glutamic acid in $20 \%$ aq. glucose } \\
\hline 298.15 & $0.9463( \pm 0.097)$ & $-0.0717( \pm 0.027)$ & 1.15 \\
\hline 303.15 & $0.9991( \pm 0.069)$ & $-0.0591( \pm 0.020)$ & 1.17 \\
\hline 308.15 & $1.3533( \pm 0.089)$ & $-0.1307( \pm 0.025)$ & 1.53 \\
\hline 313.15 & $1.2355( \pm 0.038)$ & $-0.0405( \pm 0.011)$ & 1.36 \\
\hline 318.15 & $1.1600( \pm 0.124)$ & $-0.062( \pm 0.035)$ & 1.24 \\
\hline 323.15 & $1.1873( \pm 0.146)$ & $-0.0112( \pm 0.041)$ & 1.24 \\
\hline
\end{tabular}

In this study, the values of B-coefficients are positive for all systems; so, strong solutesolvent interaction exists in L-glutamic acid in water as well as in aqueous glucose solutions of different mass fractions. Contrarily, the values of the A-coefficient are negative for all systems at different temperatures, which indicates the presence of weak solute-solute interaction. Khanuja et al. reported a similar structure-making tendency for amino acids in aqueous glucose solution [58].

\subsubsection{Hydration number.}

The hydration number, $\left(\mathrm{H}_{\mathrm{n}}\right)$ values of L-glutamic acid in aqueous-glucose solutions are also determined by using the equation [30, 59-61],

$$
\mathrm{H}_{\mathrm{n}}=\frac{B}{\varphi_{v}^{0}}
$$

The values of $\mathrm{H}_{\mathrm{n}}$ are indexed in table 4. The table discloses that the values of $\mathrm{H}_{\mathrm{n}}$ raise with raising glucose concentration for most of the studied systems, which indicates the enhancement of hydration of L-glutamic acid in the studied solution. Actually, the water molecules are substituted by glucose and act as a structure-maker by $\mathrm{H}$-bonding. $\mathrm{H}_{\mathrm{n}}$ values also increase with increasing temperature indicates the presence of solute-solvent interaction in these studied systems. Jones-Dole coefficient- B and $\varphi_{V}^{0}$ values also support the trend of hydration number, $\mathrm{H}_{\mathrm{n}}$ values. 


\subsection{Thermodynamics of viscous flow.}

Gibbs free energy of activation for a per mole of solute $\left(\Delta \mu_{2}^{0 \neq}\right)$ and solvent $\left(\Delta \mu_{1}^{0 \neq}\right)$ was calculated based on the transition state theory of the relative viscosity proposed by Feakins et al. [62-67]. According to this theory, the B-coefficient could be express by the relation,

$$
\begin{aligned}
& B=\frac{\overline{\left(V_{1}^{0}\right.}-\overline{\left.V_{2}^{0}\right)}}{1000}+\frac{\overline{V_{1}^{0}}\left(\Delta \mu_{2}^{0 \neq}-\Delta \mu_{1}^{0 \neq}\right)}{1000 R T} \\
& \Delta \mu_{1}^{0 \neq}=\mathrm{RT} \ln \left(\frac{\eta_{0} \overline{\mathrm{V}_{1}^{0}}}{\mathrm{hN}}\right) \\
& \Delta \mu_{2}^{0 \neq}=\Delta \mu_{1}^{0 \neq}+\left(\frac{\mathrm{RT}}{\overline{\mathrm{V}_{1}^{0}}}\right)\left[1000 \mathrm{~B}-\left(\overline{\mathrm{V}_{1}^{0}}-\overline{\mathrm{V}_{2}^{0}}\right)\right]
\end{aligned}
$$

Where, $\overline{V_{1}^{0}}=$ the apparent molar volume of the solvent (aqueous-sucrose) and $\overline{V_{2}^{0}}=$ the limiting apparent molar volume of the solute, respectively. $h$ and $N$ are Planck's constant and Avogadro number, respectively.

Table 5. Free energies of activation of viscous flow per mole of solvent, $\left(\Delta \mu_{1}^{0 \neq}\right)$ and per mole of solute, $\left(\Delta \mu_{2}^{0 \neq}\right)$

\begin{tabular}{|c|c|c|c|c|c|c|}
\hline & \multicolumn{6}{|c|}{$T / K$} \\
\hline Parameters & 298.15 & 303.15 & 308.15 & 313.15 & 318.15 & 323.15 \\
\hline \multicolumn{7}{|c|}{ L-glutamic acid in water } \\
\hline$\Delta \mu_{1}^{0 \neq} /\left(\mathrm{kJ} . \mathrm{mol}^{-1}\right)$ & 9.09 & 8.98 & 8.89 & 8.80 & 8.64 & 8.46 \\
\hline$\Delta \mu_{2}^{0 \neq} /\left(\mathrm{kJ}^{\mathrm{m}} \mathrm{mol}^{-1}\right)$ & 154.48 & 167.82 & 184.48 & 201.02 & 189.78 & 234.08 \\
\hline \multicolumn{7}{|c|}{ L-glutamic acid in 5\% aq. glucose } \\
\hline$\Delta \mu_{1}^{0 \neq} /\left(\mathrm{kJ} . \mathrm{mol}^{-1}\right)$ & 9.39 & 9.30 & 9.21 & 9.12 & 8.98 & 8.89 \\
\hline$\Delta \mu_{2}^{0 \neq} /\left(\mathrm{kJ} \cdot \mathrm{mol}^{-1}\right)$ & 182.60 & 192.21 & 168.54 & 208.82 & 210.83 & 193.06 \\
\hline \multicolumn{7}{|c|}{ L-glutamic acid in $10 \%$ aq. glucose } \\
\hline$\Delta \mu_{1}^{0 \neq} /\left(\mathrm{kJ} \cdot \mathrm{mol}^{-1}\right)$ & 9.77 & 9.74 & 9.68 & 9.55 & 9.43 & 9.33 \\
\hline$\Delta \mu_{2}^{0 \neq} /\left(\mathrm{kJ} \cdot \mathrm{mol}^{-1}\right)$ & 133.13 & 129.17 & 152.00 & 213.99 & 258.90 & 250.89 \\
\hline \multicolumn{7}{|c|}{ L-glutamic acid in $15 \%$ aq. glucose } \\
\hline$\Delta \mu_{1}^{0 \neq} /\left(\mathrm{kJ} . \mathrm{mol}^{-1}\right)$ & 10.41 & 10.34 & 10.20 & 10.04 & 9.91 & 9.80 \\
\hline$\Delta \mu_{2}^{0 \neq} /\left(\mathrm{kJ} \cdot \mathrm{mol}^{-1}\right)$ & 128.69 & 144.48 & 157.13 & 203.88 & 168.97 & 158.53 \\
\hline \multicolumn{7}{|c|}{ L-glutamic acid in $20 \%$ aq. glucose } \\
\hline$\Delta \mu_{1}^{0 \neq} /\left(\mathrm{kJ} \cdot \mathrm{mol}^{-1}\right)$ & 10.93 & 10.84 & 10.69 & 10.50 & 10.41 & 10.25 \\
\hline$\Delta \mu_{2}^{0 \neq} /\left(\mathrm{kJ} \cdot \mathrm{mol}^{-1}\right)$ & 133.11 & 141.67 & 187.78 & 175.48 & 168.20 & 174.00 \\
\hline
\end{tabular}
for L-glutamic acid in in water and (glucose + water) $(5 \%, 10 \%, 15 \%$ and $20 \%$ glucose, w/w) solutions at temperatures (298.15-323.15) K.

The $\left(\Delta \mu_{1}^{0 \neq}\right)$ and $\left(\Delta \mu_{2}^{0 \neq}\right)$ values are listed in table 5. It is observed that the value of $\left(\Delta \mu_{1}^{0 \neq}\right)$ and $\left(\Delta \mu_{2}^{0 \neq}\right)$ for L-glutamic acid are positive and the $\left(\Delta \mu_{2}^{0 \neq}\right)$ values are much higher than $\left(\Delta \mu_{1}^{0 \neq}\right)$ in aqueous glucose solutions. This indicates the presence of strong interaction between L-glutamic acid and solvent $(5,10,15,20 \% \mathrm{w} / \mathrm{w}$, aqueous glucose), and the interaction is greater in the ground state than in the transition state. So, it is evident that the solvation of the L-glutamic acid molecule is not as much preferred in free energy terms in the transition state [68]. The $\left(\Delta \mu_{2}^{0 \neq}\right)$ values increase with an increase in temperature for most of the systems as well as increase the solute-solvent interaction that makes it hard to flow the solute molecules.

\section{Conclusions}

This work represents the temperature based volumetric and viscometric properties of L-glutamic acid solution in water and in aqueous glucose solutions $(5,10,15$, and $20 \%$ of glucose, $w / w$ in water). Various volumetric and viscometric parameters like $\varphi_{v}, \varphi_{v}{ }^{0},\left(\Delta \varphi_{v}{ }^{0}\right)_{\text {tra, }}$, $\mathrm{E}_{\varphi}{ }^{0},\left(\delta \mathrm{E}_{\varphi}{ }^{0} / \delta \mathrm{T}\right)_{\mathrm{p}}$, coefficients-A, $\mathrm{B}, \mathrm{H}_{\mathrm{n}},\left(\Delta \mu_{1}^{0 \neq}\right)$ and $\left(\Delta \mu_{2}^{0 \neq}\right)$ were calculated from experimental data. The results narrate the presence of strong solute-solvent interactions in these studied 
systems. Hence, it is concluded from Hepler constant $\left(\delta \mathrm{E}_{\varphi}{ }^{0} / \delta \mathrm{T}\right) \mathrm{p}$, and Jones-Dole coefficient$B$ values that L-glutamic acid act as a structure-maker in aqueous glucose solutions as well as in water.

\section{Funding}

The authors are thankful to Research Cell, Khulna University, Khulna-9208, Bangladesh, for the financial support in form of research project (No. KU/Research Cell-04/2000-228).

\section{Acknowledgments}

The authors are thankful to the Head of Chemistry Discipline, Khulna University, Khulna9208, Bangladesh, for providing the necessary lab facilities.

\section{Conflicts of Interest}

The authors declare no conflict of interest.

\section{References}

1. Salimi, F.; Frouzesh, F. Volumetric and viscometric study of the ternary (dl-alanine/+d(-)-fructose + water) solution at different temperatures and atmospheric pressure. J. Chem. Thermodyn. 2018, 126, 22-30, https://doi.org/10.1016/j.jct.2018.06.008.

2. Gupta, J.; Nain, A.K. Effect of concentration and temperature on apparent molar properties of homologous a-amino acids in aqueous semicarbazide hydrochloride solutions: A quest on the concept of kosmotropic/chaotropic behavior of amino acids. J. Chem. Thermodyn. 2019, 135, 9-26, https://doi.org/10.1016/j.jct.2019.03.011.

3. Nain, A.K.; Droliya, P.; Yadav, J.; Agarwal, A. Physicochemical study of (solute+solute) and (solute+solvent) interactions of 1-asparagine and l-glutamine in aqueous-d-mannose solutions at temperatures from $(293.15$ to 318.15$) \mathrm{K}$. J. Chem. Thermodyn. 2016, 95, 202-215, https://doi.org/10.1016/j.jct.2015.11.014.

4. Hippel, P.H. Von.; Schleich, T. Ion effects on the solution structure of biological macromolecules. Acc. Chem. Res. 1969, 2, 257-265, https://doi.org/10.1021/ar50021a001.

5. Franks, F. Protein Stability: The Value of 'Old Literature'. Biophys Chem. 2002, 96, 117-27, https://doi.org/10.1016/s0301-4622(02)00014-5.

6. Kumar, H.; Behal, I. Volumetric and ultrasonic investigation of molecular interactions of 1-serine and 1threonine in aqueous nicotinamide solutions at $\mathrm{T}=(288.15-318.15)$ K. J. Mol. Liq. 2016, 219, 756-764, https://doi.org/10.1016/j.molliq.2016.04.019.

7. Kawadkar, D.V; Zodape, S.P. Thermophysical properties of dicationic ionic liquids under the influence of amino acid. J. Chem. Eng. Data. 2019, 64, 421-432, https://doi.org/10.1021/acs.jced.8b00349.

8. Riyazuddeen; Usmani, M.A. Densities, Speeds of Sound, and Viscosities of (1-Proline + Aqueous Glucose) and (1-Proline + Aqueous Sucrose) Solutions in the Temperature Range (298.15 to 323.15) K. J. Chem. Eng. Data 2011, 56, 3504-3509, https://doi.org/10.1021/je2000205.

9. Kim, Y.K.; Jones, L.S.; Dong, A.; Kendrick, B.S.; Chang, B.S.; Manning, M.C.; Randolph, T.W.; Carpenter, J.F. Effects of sucrose on conformational equilibria and fluctuations within the native-state ensemble of proteins. Protein Sci. 2003, 12, 1252-1261, https://doi.org/10.1110/ps.0242603.

10. Seitz, J.C.; Schulte, M.D.; Hall, A.S.; Rhett, G.W. Volumetric properties of dilute (D-glucose $+\mathrm{H}_{2} \mathrm{O}$ ) solutions at temperatures from (293.15 to 433.15$) \mathrm{K}$ and pressures from (0.10 to 50.00) MPa. J. Chem. Thermodyn. 2019, 128, 372-382, https://doi.org/10.1016/j.jct.2018.08.020.

11. Moghimi, M.; Roosta, A. Physical properties of aqueous mixtures of (choline chloride + glucose) deep eutectic solvents. J. Chem. Thermodyn. 2008, 129, 159-165, https://doi.org/10.1016/j.jct.2018.09.029.

12. Ankita; Nain, A.K. Volumetric, acoustic and viscometric studies of solute-solute and solute-solvent interactions of isoniazid in aqueous-glucose/sucrose solutions at temperatures from $293.15 \mathrm{~K}$ to $318.15 \mathrm{~K}$. J. Chem. Thermodyn. 2019, 133, 123-134, https://doi.org/10.1016/j.jct.2019.01.024.

13. Kumar, H.; Sharma, M.; Kumar, V. Effect of Citrate Salts on the Volumetric and Ultrasonic Properties of Sucrose in Aqueous Solutions at Temperatures $\mathrm{T}=(288.15-318.15)$ K. J. Chem. Eng. Data. 2018, 63, 37693783, https://doi.org/10.1021/acs.jced.8b00370. 
14. Nain, A.K.; Pal, R.; Sharma, R.K. Physicochemical study of solute-solute and solute-solvent interactions of 1-histidine in water+sucrose solutions at different temperatures. J. Mol. Liq. 2012, 165, 154-160, https://doi.org/10.1016/j.molliq.2011.11.003.

15. Kumar, H.; Kumaria, S.; Behala, I.; Sharma S.K. Analysing the molecular interactions of sucrose in aqueous triammonium citrate and trilithium citrate solutions at different temperatures $\mathrm{T}=(288.15-318.15) \mathrm{K}$ through volumetric and ultrasonic investigations. J. Chem. Thermodyn. 2008, 125, 17-31, https://doi.org/10.1016/j.jct.2018.05.004.

16. Zhao, Y.; Chen, Y.; Fang, M.; Zhang, H.; Zhuo, K. Volumetric and Viscosity Properties of Glycine in Ionic Liquid + Water Solutions at 298.15 K. J. Chem. Thermodyn. 2019, 130, 198-203, https://doi.org/10.1016/j.jct.2018.09.036.

17. M Wusteman, M.; Boylan, S.; Pegg, D.E. The Effect of Cooling Rate and Temperature on the Toxicity of Ethylene Glycol in the Rabbit Internal Carotid Artery. Cryobiology. 1996, 33, 423-429, https://doi.org/10.1006/cryo.1996.0042.

18. Pal, A.; Chauhan, N. Densities, speeds of sound and viscosities of L-alanine in aqueous fructose, maltose and lactose solutions at different temperatures. Indian J. Chem. 2009, 48, 1069-1077.

19. Kulikova, G.A.; Parfenyuk, E.V. Influence of side chain of L- $\alpha$-amino acids on their interaction with Dglucose in dilute aqueous solutions. J. Solution Chem. 2008, 37, 835-840, https://doi.org/10.1007/s10953008-9275-1.

20. Sharma, S. K.; Singh, G.; Kumar, H.; Kataria, R. Study of solute-solute and solute-solvent interactions of $\mathrm{N}$-acetyl glycine in aqueous d-fructose solutions at different temperatures. Thermochim. Acta 2015, 607, 18, https://doi.org/10.1016/j.tca.2015.03.015.

21. Rani, R.; Kumar, A.; Sharma, T.; Sharma, T.; Bamezai, R.K. Volumetric, acoustic and transport properties of ternary solutions of L-serine and L-arginine in aqueous solutions of thiamine hydrochloride at different temperatures. J. Chem. Thermodyn. 2019, 135, 260-277, https://doi.org/10.1016/j.jct.2019.03.039.

22. Koohyar, F.; Rostami, A.A.; Chaichi, M.J.; Kiani, F. Refractive indices, viscosities, and densities for LCysteine hydrochloride monohydrate+ D-sorbitol+ water, and glycerol+ D-sorbitol+ water in the temperature range between $\mathrm{T}=303.15 \mathrm{~K}$ and $\mathrm{T}=323.15 \mathrm{~K}$. J. Solution Chem. 2011, 40, 1361-1370, https://doi.org/10.1007/s10953-011-9714-2.

23. Ali, A.; Sabir, S.; Nain, A.; Hyder, S.; Ahmad, S.; Tariq, M.; Patel, R. Interactions of phenylalanine, tyrosine and histidine in aqueous caffeine solutions at different temperatures. J. Chin. Chem. Soc. 2007, 54, 659-666, https://doi.org/10.1002/jccs.200700094.

24. Ali, A.; Patel, R.; Khan, S.; Bhushan, V. Study of Thermodynamic and Transport Properties of Glycine, Diglycine, and Triglycine in Aqueous Tartrazine at Different Temperatures. Zeitschrift fur Naturforschung. 2009, 64, 758-764, https://doi.org/10.1515/zna-2009-1113.

25. Riyazuddeen, U. M.; Usmani, M. Interactions in (1-alanine / 1-threonine + aqueous glucose / aqueous sucrose) systems at (298.15-323.15) K. Thermochim. Acta. 2012, 527, 112-117, https://doi.org/10.1016/j.tca.2011.10.013.

26. Usmani, M.A. Densities, speeds of sound, and viscosities of (1-proline+ aqueous glucose) and (1-proline+ aqueous sucrose) solutions in the temperature range (298.15 to 323.15) K. J. Chem. Eng. Data. 2011, 56, 3504-3509, https://doi.org/10.1021/je2000205.

27. Nain, A.K.; Lather, M. Probing solute-solute and solute-solvent interactions in (l-arginine+ d-xylose/larabinose+ water) solutions at different temperatures by using volumetric and viscometric methods. J. Chem. Thermodyn. 2013, 63, 67-73, https://doi.org/10.1016/j.jct.2013.04.001.

28. Nain, A. K.; Pal, R.; Neetu. Physicochemical study of solute-solute and solute-solvent interactions of 1phenylalanine in (water+arabinose/glucose/sucrose) solutions at different temperatures. J. Chem. Thermodyn. 2014, 68, 169-182, https://doi.org/10.1016/j.jct.2013.09.008.

29. Nain, A. K.; Lather, M. Study of solute-solute and solute-solvent interactions of 1-serine in d-xylose/larabinose + water solutions using volumetric, ultrasonic and viscometric methods at different temperatures. Phys. Chem. Liq. 2015, 53, 599-618, https://doi.org/10.1080/00319104.2015.1018256.

30. Nain, A.K.; Pal, R. Study of solute-solute and solute-solvent interactions of 1-threonine in aqueous-glucose solutions at different temperatures by using volumetric and viscometric methods. J. Chem. Thermodyn. 2013, 60, 98-104, https://doi.org/10.1016/j.jct.2013.01.008.

31. Nain, A.K.; Pal, R.; Sharma, R.K. Volumetric, ultrasonic, and viscometric behaviour of 1-histidine in aqueous-glucose solutions at different temperatures. J. Chem. Thermodyn. 2011, 43, 603-612, https://doi.org/10.1016/j.jct.2010.11.017.

32. Ali, A.; Hyder, S.; Sabir, S.; Chand, D.; Nain, A.K. Volumetric, viscometric, and refractive index behaviour of $\alpha$-amino acids and their groups' contribution in aqueous d-glucose solution at different temperatures. $J$. Chem. Thermodyn. 2006, 38, 136-143, https://doi.org/10.1016/j.jct.2005.04.011.

33. Palani, R.; Geetha, A. Acoustical and thermodynamical studies of L-serine, L-glutamine and L-asparagine in aqueous D-glucose solutions at 298.15 K. Res. J. Phys. 2007, 1, 82-89, https://doi.org/10.3923/rjp.2007.82.89.

34. Kestin, J.; Sokolov, M, Wakeham, W.A. Viscosity of liquid water in range 8 to $150{ }^{0}$ C. J. Phys.Chem. Ref. Data, 1978, 7, 941-948, https://doi.org/10.1063/1.555581. 
35. Kestin, J.; Sokolov, M.; Wakeham, W.A. Viscosity of liquid water in the range $8^{0} \mathrm{C}$ to $150^{0}$ C. J. Phys. Chem. Ref. data. 1978, 7, 941-948, https://doi.org/10.1063/1.555581.

36. Rajagopal, K.; Roshan, M.M.; Shailajha, S.; Renold, G.R.R. Volumetric approach to the interaction of LProline in aqueous Metformin Hydrochloride solutions for temperature range 298.15-318.15 K. J. Chem. Thermodyn. 2019, 133, 312-319, https://doi.org/10.1016/j.jct.2019.02.012.

37. Masson, D.O. XXVIII. Solute molecular volumes in relation to solvation and ionization. Lond. Edinb. Dubl. Phil. Mag.1929, 8, 218-235, https://doi.org/10.1080/14786440808564880.

38. Ali, A.; Shahjahan, S. Volumetric and viscometric behaviour of some amino acids and their group contributions in aqueous tetramethylammonium bromide at different temperatures. Z. Phys. Chem. 2008, 222, 1519-1532, https://doi.org/10.1524/zpch.2008.5239.

39. Ren, X.; Zhu, C.; Ma, Y. Volumetric and viscometric studies of amino acids in mannitol aqueous solutions at T=(293.15 to 323.15) K. J. Chem. Eng. Data. 2015, 60, 1787-1802, https://doi.org/10.1021/je501178z.

40. Khanuja, P.; Chourey, V. The structure making and structure breaking properties of amino acids in aqueous glucose solution at different temperatures. Pelagia Research Library 2014, 5, 71-76.

41. Shekaari, H.; Zafarani-Moattar, M.T.; Mirheydari, S.N.; Faraji, S. Thermophysical Properties of 1-Hexyl-3methylimidazolium Salicylate as an Active Pharmaceutical Ingredient Ionic Liquid (API-IL) in Aqueous Solutions of Glycine and l-Alanine. J. Chem. Eng. Data. 2019, 64, 124-134, https://doi.org/10.1021/acs.jced.8b00644.

42. Patyar, P.; Kaur, T.; Sethi, O. Molecular interactions of some amino acids in aqueous 1-butyl-3methylimidazolium bromide solutions at different temperatures: A volumetric approach. J. Chem. Thermodyn. 2018, 125, 278-295, https://doi.org/10.1016/j.jct.2018.05.008.

43. Fang, S.; Ren, D.H. Effect of 1-ethyl-3-methylimidazolium bromide ionic liquid on the volumetric behavior of some aqueous L-amino acids solutions. J. Chem. Eng. Data. 2013, 58, 845-850, https://doi.org/10.1021/je300953u.

44. Pal, A.; Chauhan, N. Thermodynamic study of some amino acids, 2-aminopropanoic acid, 2-amino-3methylbutanoic acid, 2-amino-4-methylpentanoic acid, and 2-amino-3-phenylpropanoic acid in aqueous saccharide solutions at different temperatures: volumetric and ultrasonic study. J. Chem. Eng. Data. 2011, 56, 1687-1694, https://doi.org/10.1021/je100857s.

45. Kumar, H.; Kumar, S.; Behal, I. Investigations on the temperature dependent volumetric and ultrasonic properties of structural isomers D (+)-glucose and D (-)-fructose in aqueous dipotassium oxalate solutions. J. Chem. Thermodyn. 2019, 138, 229-239, https://doi.org/10.1016/j.jct.2019.06.023.

46. Zafarani-Moattar, M.T.; Shekaari, H.; Mazaher Haji Agha, E. Investigation of the Thermodynamic Properties in Aqueous Solutions Containing d-Fructose and Some Imidazolium-Based Ionic Liquids at Different Temperatures. J. Chem. Eng. Data. 2019, 64, 1385-1398, https://doi.org/10.1021/acs.jced.8b00958.

47. Sinha, B.; Sarkar, A.; Roy, P. K.; Brahman, D. Physicochemical Properties of L-Alanine in Aqueous Silver Sulphate Solutions at $(298.15,308.15$, and 318.15) K. Int J Thermophys. 2011, 32, 2062-2078, https://doi.org/10.1007/s10765-011-1060-5.

48. Yan, Z.; Chen, X.; Liu, L.; Cao, X. Molecular interactions between some amino acids and a pharmaceutically active ionic liquid domiphen DL-mandelic acid in aqueous medium at temperatures from $293.15 \mathrm{~K}$ to 313.15 K. J. Chem. Thermodyn. 2019, 138, 1-13, https://doi.org/10.1016/j.jct.2019.06.002.

49. Hepler, L.G. Thermal expansion and structure in water and aqueous solutions. Can. J. Chem. 1969, 47, 46134617, https://doi.org/10.1139/v69-762.

50. Dhondge, S.S.; Zodape, S.P.; Parwate, D.V. Volumetric and viscometric studies of some drugs in aqueous solutions at different temperatures. J. Chem. Thermodyn. 2012, 48, 207-212, https://doi.org/10.1016/j.jct.2011.12.022.

51. Rajagopal, K.; Renold, G.R.R. Studies on Volumetric and Viscometric properties of Alanine in aqueous Paracetamol solution over a range of temperature (298.15 to 318.15) K. Int. J. Adv. Eng. Res. Dev. 2017, 4, 714-722.

52. Iqbal, M.J.; Chaudhry, M.A. Thermodynamic studies on the interactions of phenyl salicylate in protic solvents at different temperatures. J. Mol. Liq. 2008, 143, 75-80, https://doi.org/10.1016/j.molliq.2008.05.014.

53. Falkenhagen, H.; Dole, M. Viscosity of electrolyte solutions and its significance to the Debye theory. Z. Phys. 1929, 30, 611-616.

54. Falkenhagen, H.; Vernon, E. The quantitative limiting law for the viscosity of simple strong electrolytes. Z. Phys. 1932, 33 .

55. Hai-Lang, Z.; Shi-Jun, H. Viscosity and density of water + sodium chloride + potassium chloride solutions at 298.15 K. J. Chem. Eng. Data. 1996, 41, 516-520, https://doi.org/10.1021/je9501402.

56. Sarma, T.; Ahluwalia, J. Experimental studies on the structures of aqueous solutions of hydrophobic solutes. Chemical Society Reviews. 1973, 2, 203-232, https://doi.org/10.1039/CS9730200203.

57. Siddique, J.A.; Naqvi, S. Viscosity behavior of $\alpha$-amino acids in acetate salt solutions at temperatures (303.15 to 323.15) K. Int. J. Thermophys. 2012, 33, 47-57, https://doi.org/10.1007/s10765-011-1111-y. 
58. Khanuja, P; Chourey, V.R. The structure making and structure breaking properties of amino acids in aqueous glucose solution at different temperatures. Pelagia Research Library. 2014, 5, 71-76.

59. Bai, T.C.; Yan, G.B. Viscosity B-coefficients and activation parameters for viscous flow of a solution of heptanedioic acid in aqueous sucrose solution. Carbohydr. Res. 2003, 338, 2921-2927, https://doi.org/10.1016/j.carres.2003.08.006.

60. Banerjee, T.; Kishore, N. Interactions of some amino acids with aqueous tetraethylammonium bromide at 298.15 K: a volumetric approach. J. Solution Chem. 2005, 34, 137-153, https://doi.org/10.1007/s10953-0052746-8.

61. Desnoyers, J.E.; Perron, G. The viscosity of aqueous solutions of alkali and tetraalkylammonium halides at 25ㄷ. J. Solution Chem. 1972, 1, 199-212, https://doi.org/10.1007/BF00645101.

62. Feakins, D.; Freemantle, D.J.; Lawrence, K.G. Transition state treatment of the relative viscosity of electrolytic solutions. Applications to aqueous, non-aqueous and methanol+ water systems. J. Chem. Soc. Faraday Trans. 1, 1974, 70, 795-806, https://doi.org/10.1039/F19747000795.

63. Kaminsky, M. Ion-solvent interaction and the viscosity of strong-electrolyte solutions. Discuss. Faraday Soc. 1957, 24, 171-179, https://doi.org/10.1039/DF9572400171.

64. Bai, T.C.; Yan, G.B. Viscosity B-coefficients and activation parameters for viscous flow of a solution of heptanedioic acid in aqueous sucrose solution. Carbohydr. Res. 2003, 338, 2921-2927, https://doi.org/10.1016/j.carres.2003.08.006.

65. Banerjee, T.; Kishore, N. Interactions of some amino acids with aqueous tetraethylammonium bromide at 298.15 K: a volumetric approach. J. Solution Chem. 2005, 34, 137-153, https://doi.org/10.1007/s10953-0052746-8.

66. Desnoyers, J.; Perron, G. The viscosity of aqueous solutions of alkali and tetraalkylammonium halides at 25 C. J. Solution Chem. 1972, 1, 199-212, https://doi.org/10.1007/BF00645101.

67. Feakins, D.; Bates, F.M.; Waghorne, W.E.; Lawrence, K.G. Relative viscosities and quasi-thermodynamics of solutions of tert-butyl alcohol in the methanol-water system: a different view of the alkyl-water interaction. J. Chem. Soc.; Faraday Trans. 1993, 89, 3381-3388, https://doi.org/10.1039/FT9938903381.

68. Feakins, D.; Bates, F.M.; Waghorne, W.E.; Lawrence, K.G. Relative viscosities and quasi-thermodynamics of solutions of tert-butyl alcohol in the methanol-water system: a different view of the alkyl-water interaction. J. Chem. Soc.; Faraday Trans. 1993, 89, 3381-3388, https://doi.org/10.1039/FT9938903381. 